DOI 10.26724 / 2079-8334-2017-4-62-104-107

UDC 616.(314.5+314.16)-079-055.1(477)

M. M. Shinkaruk-Dykovytska, V. O. Orlovskiy, A. O. Gavrilyuk, G. V. Datsenko, T. R. Zakalata National Pirogov Memorial Medical University, Vinnitsa

\title{
DIFFERENCES IN COMPUTER-TOMOGRAPHIC SIZE OF PREMOLAR TEETH AND THEIR ROOTS IN PRACTICALLY HEALTHY MEN OF DIFFERENT CRANIOTYPES, INHABITANTS OF THE CENTRAL REGION OF UKRAINE
}

e-mail: m.dykovytska@gmail.com

In practically healthy men of the central region of Ukraine, the largest number of statistically significant or tendencies to differences in the linear computational-tomographic size of premolar teeth and their roots was established by comparing dolichocephals and mesocephals with brachycephals and hyperbrachycephals. Brachycephals and hyperbrachycephals show the highest values of both vertical and transverse sizes of premolar teeth compared to those of other craniotypes (mainly due to the vestibule-lingual and mesiodistal dimensions of the crown and neck of the tooth). Between men dolichocephals and mesocephals, in general, no statistically significant or tendency differences of computer-tomographic size of premolar teeth and their roots were found. of Ukraine.

Key words: premolar teeth, computer tomography, practically healthy men, craniotypological features, central region

The dimensions of premolar teeth belong to the most objective criteria for the diagnosis and planning of orthodontic treatment. Determining the ideal size of the teeth remains a difficult task due to individual variations and erosion with the age of the proximal surface of the teeth $[10,17]$. To determine the correct individual size of teeth, physicians have been suggested to use the mathematical theorem - the "golden section" [9]. However, it later became known that for dentistry the use of the golden proportion is too tough. For example, if strict adherence to it can be observed excessive narrowness of jaw arches and compression of lateral segments of teeth $[8,16]$.

It should be noted that the vertical and transverse dimensions of the teeth depend not only on the size of the jaws and dental arches, but also on the parameters of the craniofacial complex. Studying the parameters of premolar teeth in persons of different craniotypes can be successfully applied in their modeling during restoration. Their values can serve as useful benchmarks for the diagnosis and planning of treatment for upper and lower jaw teeth $[4,11]$. However, such important and clinically significant aspects of dental aesthetics and orthodontics as the ratio of parameters of small angular teeth to the type of skull are practically not presented in scientific sources.

Research purpose - to determine the features of linear computer-tomographic sizes of premolar teeth and their roots in practically healthy men of different craniotypes, residents of the central region of Ukraine.

Material and methods. On the basis of the medical center "Vinintermed LTD", 64 somatically healthy men aged from 19 to 35 years from the central region of Ukraine (residents from Vinnitsa, Cherkasy, Kirovograd, Poltava and Dnipropetrovsk regions) conducted a cone-ray computer tomography with the help of a dental cone-ray tomograph Veraviewepocs-3D (Morita, Japan). The volume of a threedimensional image is a cylinder of $8 \times 8 \mathrm{~cm}$, a layer thickness of $0,2 / 0,125 \mathrm{~mm}$, an irradiation dose of $0,011-0,048 \mathrm{mSv}$, a voltage and current strength of $60-90 \mathrm{kV} / 2-10 \mathrm{~mA}$. The study of a three-dimensional model of bone structures of the tooth-jaw complex was carried out in the i-Dixel One Volume Viewer (Ver.1.5.0, J Morita Mfg. Cor.) [2, 13].

Bioethics Committee of National Pirogov Memorial Medical University (protocol № 8 dated 10.09.2013) found that the studies fully met ethical and moral-legal requirements in accordance with the Order of the Ministry of Health of Ukraine № 281 of November 1, 2000 and do not contradict the basic bioethical norms of the Helsinki Declaration, the Council of the Convention Europe on Human Rights and Biomedicine (1977).

On cone-ray computer tomograms premolar teeth of the upper and lower jaws were measured: the length of the tooth; the length of palatal and cheek's roots of premolar teeth of the upper and lower jaw; height of tooth crown; vestibule-lingual dimensions of the crown and neck of the tooth; mesio-distal dimensions of the crown and neck of the tooth [15].

The cephalometric study consisted of determining the parameters of the cerebral and facial sections of the head with the help of a large sliding compass with a scale in the real size of the Martin system and soft centimeter ribbon. Cephalometric studies were conducted taking into account the generally accepted recommendations and anatomical points $[1,3]$. The shape of the head was determined 
by the formula ms_ms * $100 /$ g_op, where ms_ms - the largest head width (occipital diameter); g_op the largest length of the head (distance from glabella to opistocranion) [18]. Up to a value of 75.9 men attributed to dolichocephals; 76.0-80.9 - to mesocephals; 81.0-85.4 - for brachycephals; 85.5 and more to hyperbrachycephals. The following distribution is established: dolichocephals - 11; mesocephals - 16; brachycephals - 25; hyperbrachycephals - 12 .

Statistical processing of the obtained results was carried out using the statistical software package "Statistica 6.1" using nonparametric methods.

Results and its discussion. When comparing linear computer-tomographic sizes of premolar teeth and their roots between practically healthy men of different craniotypes, the inhabitants of the central region of Ukraine established the following differences: in men dolichocephals compared with brachycephals: - the height of the crown of the upper right and left first premolar teeth is statistically significantly lower (correspondingly $6.85 \pm 0.86$ and $7.46 \pm 0.90 ; 6.87 \pm 0.94$ and $7.55 \pm 0.95 ; \mathrm{p}<0.05$ in both cases); vestibule-lingual size of the crown of the lower left second premolar tooth is statistically significantly smaller ( $7.82 \pm 1.04$ and $8.46 \pm 0.72$, respectively, $\mathrm{p}<0.05$, respectively), and the mesiodistal size of the neck of a similar tooth has a pronounced tendency to lower values (respectively, $5.22 \pm$ 0.68 and $5.64 \pm 0.26 ; p=0.059$ ); vestibule-lingual size of the neck of the lower left first premolar tooth is statistically significantly smaller $(6.7 \pm 1.17$ and $7.26 \pm 0.71$, respectively; $p<0.05)$, and the mesio-distal size of the cervix of a similar tooth has a pronounced tendency to lower values (correspondingly, $5.10 \pm$ 0.73 and $5.16 \pm 0.62 ; \mathrm{p}=0.057)$; mesio-distal size of the cervix of the lower first right premolar tooth is statistically significantly smaller (correspondingly, 5,04 $\pm 0,76$ and 5,75 $\pm 0,76 ; p<0,05$ ); the vestibulelingual size and the mesio-distal size of the crown of the lower right second premolar tooth are statistically significantly smaller (correspondingly, $7.86 \pm 0.89$ and $8.47 \pm 0.71 ; 6.74 \pm 0.70$ and $7.20 \pm$ 0,$48 ; \mathrm{p}<0.05$ in both cases), and the height of the crown and the mesio-distal size of the neck of a similar tooth tend to lower values (correspondingly $6.63 \pm 1.08$ and $7.21 \pm 0.52 ; 5.22 \pm 0.72$ and $5.67 \pm 0.28 ; \mathrm{p}=$ 0.071 and $\mathrm{p}=0.056$ ); - in males of dolichocephals in comparison with hyperbrachycephals: vestibulelingual size of cervix of upper right second premolar tooth is statistically significantly lower (correspondingly, $7.48 \pm 1.63$ and $8.99 \pm 0.59 ; \mathrm{p}<0.05$ ), and vestibule-lingual crown size of a similar tooth tends to be smaller $(8.61 \pm 1.27$ and $9.49 \pm 0.73$ respectively; $p=0.069)$; vestibule-lingual size of the neck of the upper left second premolar tooth is statistically significantly lower (correspondingly, 7.43 \pm 1.60 and $8.60 \pm 1.30 ; \mathrm{p}<0.05$ ), and the vestibule-lingual crown size of a similar tooth has a slight tendency to a lower value (correspondingly, $8.57 \pm 1.27$ and $9.42 \pm 0.93 ; \mathrm{p}=0.074$ ); vestibule-language dimensions of the neck and crowns of the lower left second premolar tooth are statistically significantly lower (correspondingly $6.73 \pm 1.52$ and $7.82 \pm 0.63 ; 7.82 \pm 1.04$ and $9.42 \pm 0.93 ; \mathrm{p}<0.05$ ), while the mesio-distal size of the neck of a similar tooth tends to be lower (correspondingly, $5.22 \pm 0.68$ and $5.69 \pm$ $0.39 ; \mathrm{p}=0.068)$; the vestibule-lingual size of the neck of the lower first premolar tooth is statistically significantly lower $(6.56 \pm 1.11$ and $7.35 \pm 0.55$, respectively; $\mathrm{p}<0.05$ respectively), and the vestibulelingual crown size of a similar tooth tends to be smaller values (respectively, $7.42 \pm 1.02$ and $8.15 \pm 0.59$; $\mathrm{p}=0.069)$; the vestibule-lingual crown size of the lower right second premolar tooth has a pronounced tendency to lower values (correspondingly $7.86 \pm 0.89$ and $8.58 \pm 0.62 ; \mathrm{p}=0.056$ ), and the mesio-distal size of the crown of the lower right second premolar tooth has a slight tendency to lower values (correspondingly, $6.74 \pm 0.70$ and $7.10 \pm 0.35 ; \mathrm{p}=0.079$ ); - in men mesocephals in comparison with brachycephals: vestibule-lingual size of the cervix and crowns of the upper right first premolar tooth is statistically significantly smaller $(7.86 \pm 1.40$ and $8.67 \pm 0.85$ respectively; $8.75 \pm 1.15$ and $9,50 \pm 0.79 ; p$ $<0.05-0.01$ ); the mesio-distal size of the crown and neck of the upper right first premolar tooth is statistically significantly smaller (correspondingly, $6.32 \pm 0.56$ and $6.77 \pm 0.56 ; 4.93 \pm 0.54$ and $5.13 \pm$ $0.42 ; \mathrm{p}<0.05-0.01$ ); vestibule-lingual size of the crown and neck of the upper left first premolar tooth is statistically significantly smaller $(8,73 \pm 1,24$ and $9,51 \pm 0,83$ respectively; $7,86 \pm 1,40$ and $8,70 \pm 0,88 ; p$ $<0.05$ ), and the height of the crown of the one-name tooth tends to lower values (correspondingly $6.82 \pm$ 1.24 and $7.55 \pm 0.95, \mathrm{p}=0.061$ ); the mesio-distal size of the crown and neck of the upper left first premolar tooth is statistically significantly smaller (correspondingly $6.24 \pm 0.54$ and $6.72 \pm 0.48 ; 4.74 \pm$ 0.46 and $5.11 \pm 0.47 ; \mathrm{p}<0.05-0.01)$; vestibule-lingual crown size of the lower left second premolar tooth is statistically significantly smaller $(7.93 \pm 0.82$ and $8.47 \pm 0.72$, respectively; $p<0.05)$, and the vestibule-lingual size of the neck of a similar tooth has a significant tendency to lower values (correspondingly, $6.94 \pm 1.18$ and $7.58 \pm 0.76 ; p=0.053$ ); the height of the crown, the mesio-distal size of the crown and neck of the lower left second premolar tooth are statistically significantly lower (correspondingly, $6.60 \pm 1.00$ and $7.36 \pm 0.53 ; 6.64 \pm 0.82$ and $7.18 \pm 0,44 ; 5.33 \pm 0.42$ and $6.64 \pm 0.26$; p <0.05-0.01); vestibule-lingual and mesio-distal dimensions of the neck and similar sizes of the crown 
and the lower left of the first premolar tooth are statistically significantly smaller (respectively $6.48 \pm$ 0.82 and $7.26 \pm 0.71 ; 5.16 \pm 0.82$ and $5,75 \pm 0.77 ; 7.45 \pm 0.61$ and $8.04 \pm 0.61 ; 6.48 \pm 0.67$ and $6.99 \pm$ 0.56; $\mathrm{p}<0.05-0.01$ ); vestibule-lingual and mesio-distal dimensions of the neck and similar sizes of crown and lower right first premolar tooth are statistically significantly smaller (correspondingly, $6.52 \pm 0.81$ and $7.16 \pm 0.69 ; 5.13 \pm 0.57$ and $5,62 \pm 0.51 ; 7.34 \pm 0.70$ and $8.04 \pm 0.60 ; 6.44 \pm 0.64$ and $6.98 \pm 0.53$; $\mathrm{p}<0.05-0.01$ ); vestibule-lingual and mesio-distal dimensions of the neck and similar sizes of crown and lower right second premolar tooth are statistically significantly smaller (respectively $6.91 \pm 0.07$ and 7.63 $\pm 0.77 ; 5.33 \pm 0.46$ and $5,67 \pm 0.28 ; 7.95 \pm 0.63$ and $8.47 \pm 0.71 ; 6.78 \pm 0.72$ and $7.29 \pm 0.40, p<0.05-$ $0.01)$; - in men mesocephals in comparison with hyperbrachycephals: the vestibule-lingual size of the cervix and crowns of the upper right second premolar tooth tend to lower values (correspondingly $7.80 \pm$ 1.45 and $8.91 \pm 0.58 ; 8.71 \pm 1.18$ and $9.49 \pm 0.73 ; p=0.060$ and $p=0.078$ ); the height of the upper left first premolar tooth and the mesio-distal crown size of a similar tooth are statistically significantly lower (respectively, $20.45 \pm 1.64$ and $21.90 \pm 1.44 ; 6.24 \pm 0.54$ and $6.62 \pm 0,22 ; \mathrm{p}<0.05-0.01$ ); the vestibulelingual size of the neck and crowns of the lower left second premolar tooth is statistically significantly lower $(6.94 \pm 1.18$ and $7.82 \pm 0.63 ; 7.93 \pm 0.82$ and $8.66 \pm 0.55$ respectively; $p<0.05-0.01)$; the height of the lower left second premolar tooth, the height of its crown tends to lower values (respectively $22.41 \pm$ 2.14 and $23.88 \pm 1.43 ; 6.60 \pm 1.00$ and $7.24 \pm 0.77 ; p=0,051$ and $p=0,063$ ); the mesio-distal size of the neck of the lower left second premolar tooth is statistically significantly lower (correspondingly $6.60 \pm$ 1.00 and $7.36 \pm 0.53 ; p<0.05-0.01$ ); vestibule-lingual size of the cervix and crowns of the lower left first premolar tooth is statistically significantly lower (correspondingly $6.48 \pm 0.82$ and $7.34 \pm 0.57 ; 7.93 \pm$ 0.82 and $8.13 \pm 0.57 ; \mathrm{p}<0.01$ in both cases); the vestibule-lingual size of the neck and crowns, the mesiodistal dimension of the lower right first premolar tooth is statistically significantly lower (correspondingly, $6.52 \pm 0.81$ and $7.35 \pm 0.55 ; 7.34 \pm 0.70$ and $8.15 \pm 0,59 ; 6.48 \pm 0.67$ and $6.97 \pm 0.24$; $\mathrm{p}<0.05-0.01$ ); the vestibule-lingual size of the cervix and crowns of the lower right second premolar tooth is statistically significantly lower (correspondingly $6.91 \pm 1.07$ and $7.88 \pm 0.63 ; 7.95 \pm 0.63$ and $8.58 \pm 0.62 ; \mathrm{p}<0.05$ in both cases).

According to the results of a number of papers [5-7, 12, 14], there are covariates between the dimensions of angular teeth and cephalometric indices and skull in general, which is explained by their phylogenetic, ontogenetic and morpho-functional unity. In individuals of different craniotypes, the correlations differed both in strength and in the direction that justifies the existence of private odontometric morphological variants and the feasibility of separation of the subjects by the type of skull. Moreover, in most works between representatives of extreme craniotypes more statistically significant differences in the size of corner teeth are established.

We also have set the largest number of statistically significant or tendencies of craniotypological differences in the linear computational-tomographic sizes of premolars teeth and their roots when comparing practically healthy men of the central region of Ukraine with dolichocephals and mesocephals, with brachycephals and hyperbrachycephals. Between men dolichocephals and mesocephals, in general, no statistically significant or tendency differences of computer-tomographic size of premolar teeth and their roots were found. Brachycephals and hyperbrachycephals show the highest values of both vertical and transverse sizes of small angular teeth in comparison with men dolichocephals and mesocephals (mainly due to vestibule-lingual and mesiodistal dimensions of the crown and neck of the tooth).

The results obtained by us confirm the scientific data that the linear dimensions of premolar teeth have craniotypological differences, which is important for orthodontists in the planning of individualized treatment of pathological abnormalities of these anatomical formations. Also promising is the study of covariances of linear computational-tomographic sizes of premolar teeth and their roots with cephalometric indices in practically healthy men of Ukraine, which will facilitate the development and determination of indications for the choice of methods of orthodontic treatment for representatives of different craniotypes.

\section{Conclusions}

1. In practically healthy men inhabitants of the central region of Ukraine with brachycephalic and hyperbrachycephalic forms of the skull, the greatest values of the vestibule-lingual and mesiodistal dimensions of the crown and neck, as well as the height of the crown of premolar teeth, were determined in comparison with the representatives of the dolichocephalic and mesocephalic form of the skull.

2. Between practically healthy men dolichocephals and mesocephals did not establish any statistically significant or tendency differences of premolar teeth and their roots. 
References

1. Alekseev V. P., \& Debets G. F. Kraniometriya. Metodika antropologicheskih issledovaniy. M.: Nauka; 1964. (in Russian)

2. Arzhantsev A. P., Ahmedova Z. R., Perfilev S. A., Vinnichenko Yu. A. Konusno-luchevaya kompyuternaya tomografiya pri endodonticheskom lechenii zubov: Novaya meditsinskaya tehnologiya. M., GEOTAR-Media; 2010. (in Russian)

3. Bunak V. V. Antropometriya. Prakticheskiy kurs. M.: Uchpedgiz; 1941. (in Russian)

4. Gayvoronskiy I. V., Gayvoronskiy A. I., Gayvoronskaya M. G., Dubovik E. I., Kevorkova S. A., Koltunov A. V., Schanikova A. S. Kraniometricheskie korrelyatsii zubochelyustnoy sistemyi, visochno-nizhnechelyustnogo sustava i litsevogo cherepa u vzroslogo cheloveka. Morfologiya. 2008; 133(2): 29. (in Russian)

5. Glushak A. A. Vestibulo-oralni rozmiri zubiv u hlopchikiv ta divchatok $\mathrm{z}$ ortognatichnim prikusom $\mathrm{v}$ zalezhnosti vid formi golovi ta tipu oblichchya. VIsnik Vinnitskogo natsionalnogo medichnogo universitetu. 2015; 19(1): 37-43. (in Ukraine)

6. Glushak A. A., Gunas I. V., Lisnichuk N. E., Samoylenko A. V. Vertikalnyie razmeryi zubov u podrostkov Podolya s ortognaticheskim prikusom v zavisimosti ot formyi golovyi i tipa litsa. Biologiya va tibbiyot muammolari. 2015; 2(83): 28-37. (in Russian)

7. Gunas I., Glushak A., Samoylenko A. Dental arch Transversal characteristics in boys and girlswith orthognathic bite: head shape and face type dependence. Current Issues in Pharmacy and Medical Sciences. 2015; 28(1): 44-47.

8. Kolesnikov L. L., \& Arutyunov S. D. Anatomiya, fiziologiya i biomehanika zubochelyustnoy sistemyi. M.: GEOTAR-Media; 2009. (in Russian)

9. Lutskaya I. K. Esteticheskaya funktsiya zuba. Nauchno-prakticheskiy zhurnal. Sovremennaya stomatologiya. 2003; 1: 30-37. (in Russian)

10. Lomiashvili L. M., \& Pogodaev D. V. Variabelnost form molyarov zubochelyustnogo apparata cheloveka. Izd-vo «DentArt». 2005; 1: 18-27. (in Russian)

11. Mirgazizov M. Z., Smerdina L. N., Koshkin G. A., Smerdina Yu. G. Kraniologicheskoe issledovanie - vazhnyiy metod izucheniya stomatologicheskoy patologi. Stomatologiya. 1999; 5: 17-25. (in Russian)

12. Nanda R. S. The contribution of craniofacial growth to clinical orthodontics. American journal orthodontics and dentofacial orthopedics. 2000; 117(5): 45-56.

13. Naumovich S. S., \& Naumovich S. A. Konusno-luchevaya kompyuternaya tomografiya: sovremennyie vozmozhnosti i perspektivyi primeneniya v stomatologi. Sovremennaya stomatologiya, 2012; 2: 31-36. (in Russian)

14. Noback M. L. \& Harvati K. Covariation in the Human Masticatory Apparatus. The anatomical record. 2015; $298:$ 64-84.

15. Proffit U. R. (per. s angl.; pod red. L.S. Persina). Sovremennaya ortodontiya. M.: MEDpress-inform; 2006. (in Russian)

16. Romanovskaya A. P., Zhurochko, E. I., Piltyay, V. I., Timoschenko, V. G., Syisoev, N. P. Antropometriya litsa, esteticheskaya norma. Prakticheskoe primenenie v stomatologii. Simferopol: «Tavriya»; 2004. (in Russian)

17. Yanushevich O. O. Meditsinskaya i klinicheskaya genetika dlya stomatologov. M.: GEOTAR-Media; 2008. (in Russian)

18. Zubov A. A. Odontologiya. Metodika antropologicheskih issledovaniy. M.: «Nauka»; 2003. (in Russian)

\begin{tabular}{|c|c|}
\hline & \\
\hline $\begin{array}{l}\text { ВІДМІННОСТІ КОМП'ЮТЕРНО-ТОМОГРА- } \\
\text { ФІЧНИХ РОЗМІРІВ МАЛИХ КУТНІХ ЗУБІВ ТА ЇХ } \\
\text { КОРЕНІВ У ПРАКТИЧНО ЗДОРОВИХ ЧОЛОВІКІВ } \\
\text { РІЗНИХ КРАНІОТИПІВ, МЕШКАНЦІ } \\
\text { ЦЕНТРАЛЬНОГО РЕГІОНУ УКРАЇНИ } \\
\text { Шінкарук-Диковицька М. М., Орловський В. О., } \\
\text { Гаврилюк А. О., Даценко Г. В., Закалата Т. Р. } \\
\text { In practically healthy mеn of the central region of } \\
\text { Ukraine, the largest number of statistically significant or } \\
\text { tendencies to differences in the linear computational- } \\
\text { tomographic size of premolar teeth and their roots was } \\
\text { established by comparing dolichocephals and mesocephals } \\
\text { with brachycephals and hyperbrachycephals. Brachycephals } \\
\text { and hyperbrachycephals show the highest values of both } \\
\text { vertical and transverse sizes of premolar teeth compared to } \\
\text { those of other craniotypes (mainly due to the vestibule- } \\
\text { lingual and mesiodistal dimensions of the crown and neck of } \\
\text { the tooth). Between men dolichocephals and mesocephals, in } \\
\text { general, no statistically significant or tendency differences of } \\
\text { computer-tomographic size of premolar teeth and their roots } \\
\text { were found. } \\
\text { Кey words: premolar teeth, computer tomography, } \\
\text { practically healthy men, craniotypological features, central } \\
\text { region of Ukraine. }\end{array}$ & 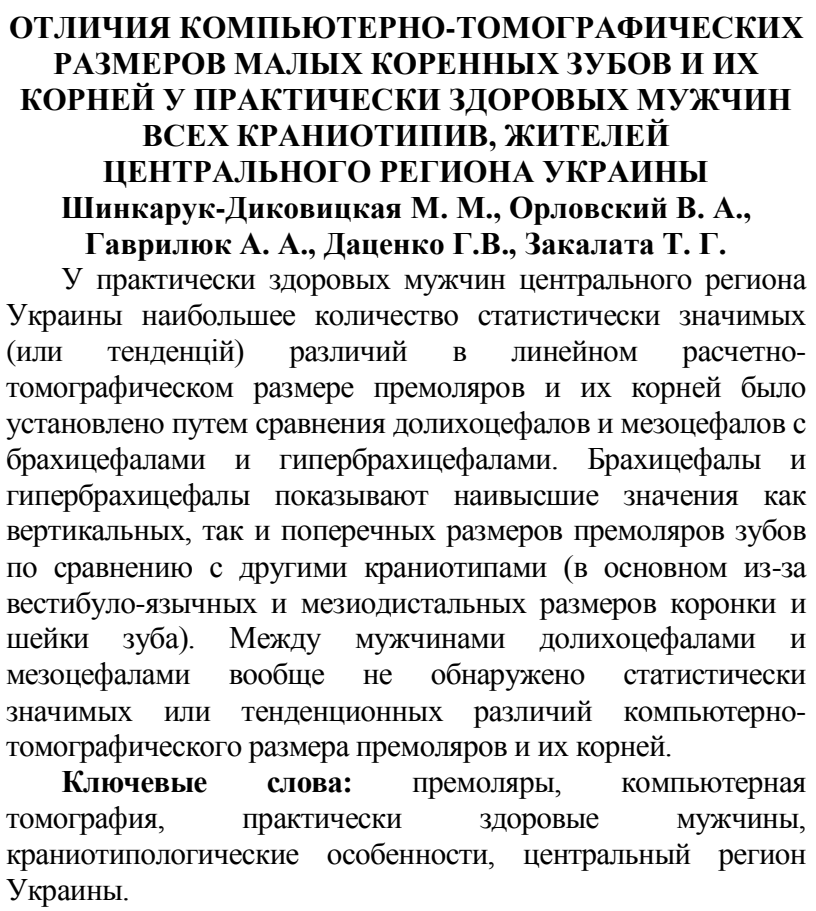 \\
\hline
\end{tabular}

